\title{
ANALISIS POLA PERUBAHAN PENGGUNAAN LAHAN DAN PERKEMBANGAN WILAYAH DI KOTA BEKASI, PROVINSI JAWA BARAT
}

\section{Analysis of Land Use Change Pattern and Regional Development in Bekasi City, West Java Provinces}

\author{
Santun Risma Pandapotan Sitorus'1*, Citra Leonataris²), dan Dyah Retno Panuju1) \\ 1) Departemen Ilmu Tanah dan Sumberdaya Lahan, Fakultas Pertanian IPB, Jl. Meranti Kampus IPB Darmaga, \\ Bogor 16680 \\ 2) Alumni Program Studi Manajemen Sumberdaya Lahan Fakultas Pertanian IPB, J1. Meranti Kampus IPB \\ Darmaga, Bogor 16680
}

\begin{abstract}
As a region developed, the increase of population increase the quality and quantity of life standard and facilities required, which cause land use changes.The objectives of the study were: (1) to observe the changing pattern of land use of Bekasi city in 2003 and 2010, (2) to identify the land use inconsistencies based on space allocation in the Regional Spatial Plan (RTRW) period of 2000-2010, (3) to identify the regional development of Bekasi city in 2003 and 2006 , and (4) to determine the factors influencing the land use change. The methods used include spatial analysis, inconcistency, skalogram, and multiple regression analyses. The built up area of Bekasi in years of 2003-2010 had increased significantly. It correlated to development of education facilities, industrial area, disordered and ordered settlements from 10,188 ha (47.5\%) to 12,061 ha (55.8\%). Inconsistence of empirical land use to land allocation of Bekasi was 301 ha in 2003 increased to 377 ha in 2010. The greatest proportion of the inconsistence to Regional Spatial Plan in 2003 and 2010 occurred on land allocated for city garden which factually were used as built up area and agricultural land. In 2003, most of villages possessed $3^{\text {rd }}$ hierarchy (48\%), and in 2006 they were mostly $2^{\text {nd }}$ hierarchy (46\%). The Factors significantly influenced land use change in Bekasi were allocation for built up area, allocation for agriculture and for city park/forest, hectarage of paddy field, mixed garden, dryland and open space in 2003, distance to another town or suburban, number of additional educational, health, and social facilities, distance to the center of social facilities, to the civic, to the center of economic facilities and population growth, respectively.
\end{abstract}

Keywords: Inconsistence of allocation, land use change, regional development, spatial utilization

\begin{abstract}
ABSTRAK
Kemajuan pembangunan di suatu wilayah sejalan dengan peningkatan jumlah penduduk akan selalu diiringi dengan meningkatnya standar kualitas dan kuantitas kebutuhan hidup dan peningkatan kebutuhan ketersediaan fasilitas yang menyebabkan terjadinya perubahan penggunaan lahan. Penelitian ini bertujuan untuk: (1) mengetahui pola perubahan penggunaan lahan Kota Bekasi Tahun 2003 dan 2010, (2) mengidentifikasi dan membandingkan pemanfaatan ruang saat ini dan alokasi ruang menurut RTRW Kota Bekasi periode 2000-2010, (3) mengkaji tingkat perkembangan wilayah Kota Bekasi tahun 2003 dan 2006, serta (4) mengetahui faktor-faktor yang mempengaruhi perubahan penggunaan lahan. Analisis data yang digunakan adalah analisis spasial pada citra, analisis skalogram, analisis inkonsistensi pemanfaatan ruang, serta analisis regresi berganda (multiple regression). Penggunaan lahan terbangun di Kota Bekasi dari tahun 2003 sampai 2010 mengalami peningkatan cukup signifikan terkait dengan pembangunan fasilitas pendidikan, kawasan industri, permukiman tidak teratur, dan permukiman teratur dari semula sebesar 10,188 ha (47.1\%) menjadi 12,061 ha (55.8\%). Kondisi penggunaan lahan di Kota Bekasi tahun 2003 menunjukkan inkonsistensi dengan alokasi ruang dalam rencana tata ruang wilayah sebesar 301 ha dan tahun 2010 sebesar 377 ha. Proporsi penyimpangan terbesar dari luas pada RTRW pada tahun 2003 dan 2010 terjadi pada lahan yang dialokasikan sebagai taman/hutan kota menjadi ruang terbangun, lahan kosong, dan lahan pertanian. Tingkat perkembangan wilayah pada tahun 2003, didominasi oleh kelurahan yang memiliki tingkatan hirarki III sebesar $48 \%$ dan pada tahun 2006 didominasi kelurahan yang berhirarki II sebesar 46\%. Faktor-faktor yang mempengaruhi perubahan penggunaan lahan di Kota Bekasi secara signifikan berturut-turut adalah alokasi RTRW untuk lahan terbangun, alokasi RTRW untuk pertanian, luas TPLB tahun 2003, luas kebun campuran tahun 2003, luas TPLK tahun 2003, luas lahan kosong tahun 2003, jarak ke kota atau kabupaten lain, alokasi RTRW untuk taman/hutan kota, pertambahan fasilitas pendidikan, pertambahan fasilitas kesehatan, pertambahan fasilitas sosial, jarak menuju pusat fasilitas sosial, jarak menuju kecamatan, jarak menuju pusat fasilitas ekonomi dan pertambahan jumlah penduduk.
\end{abstract}

Kata kunci: Inkonsistensi alokasi, perubahan penggunaan lahan, perkembangan wilayah, pemanfaatan ruang 


\section{PENDAHULUAN}

Perubahan penggunaan lahan merupakan fenomena global yang menjadi perhatian peneliti di berbagai negara di dunia. Kajian perubahan penggunaan lahan berkembang sangat cepat dan menghasilkan banyak pendekatan.Verburg et al. (2004) menyatakan bahwa dalam pemodelan perubahan penggunaan lahan ini paling tidak terdapat enam aspek yang harus diperhatikan, yaitu: cakupan analisis, dinamika silang-skala (cross-scale), faktor pemicu, interaksi spasial dan dampak kedekatan lokasi, dinamika antar waktu dan proses penggabungan. Keenam aspek tersebut merupakan topik utama dalam kajian perubahan penggunaan lahan.

Dalam kajiannya tentang perubahan penggunaan lahan di Pulau Jawa,Verburg et al. (1999) menyatakan bahwa pertumbuhan penduduk yang sangat cepat berakibat pada perluasan areal dan intensifikasi pertanian di Pulau Jawa. Kajiannya tersebut juga menduga pola perubahan penggunaan lahan pada periode 1994-2010 dan menunjukkan bahwa perubahan penggunaan lahan akan intensif terutama di wilayah dataran rendah.

Penelitian lain yang dilakukan oleh Irawan (2005; 2008) secara spesifik mengungkapkan bahwa penurunan luas lahan sawah per tahun di Jawa pada periode 19781998, berdasarkan data statistik provinsi, kurang lebih sebesar 24 ribu ha tahun $^{-1}$, sedangkan berdasarkan data statistik kabupaten sebesar kurang lebih 55 ribu ha tahun ${ }^{-1}$. Gambaran tersebut menunjukkan adanya permasalahan ketidakkonsistenan data statistik untuk kajian perubahan penggunaan lahan, serta peringatan adanya ancaman dalam upaya mempertahankan ketahanan pangan akibat perubahan penggunaan lahan.

Dalam cakupan lebih kecil yaitu wilayah Bandung Utara, Ruswandi et al. (2007) menunjukkan fenomena penyusutan kawasan pertanian secara nyata di wilayah tersebut pada periode 1992-2002. Penyusutan tersebut terutama menjadi berbagai jenis lahan terbangun seperti: villa, hotel, perumahan, perkantoran dan jenis bangunan lainnya.

Bekasi merupakan wilayah di sebelah Timur Jakarta yang merupakan daerah yang sangat dinamis. Dinamika aktifitas perekonomian dan perubahan penggunaan lahan terjadi semakin intensif dalam dua dekade terakhir (Firman, 2009). Konversi lahan pertanian di wilayah Bekasi dan wilayah berbatasan langsung dengan ibukota Jakarta lainnya yaitu Bogor dan Tangerang terjadi cukup intensif, yang salah satunya adalah akibat proses suburbanisasi (Rustiadi dan Panuju, 1999) serta lemahnya kontrol pemanfaatan ruang (Firman, 2009). Perubahan penggunaan lahan di Kota Bekasi diduga merupakan dampak dari pertumbuhan perekonomian yang pesat di Kota Jakarta. Pertumbuhan tersebut menyebabkan kebutuhan lahan untuk aktivitas ekonomi semakin meningkat, sementara ketersediaan lahan di Kota Jakarta semakin terbatas. Akibatnya terjadi perkembangan lahan terbangun yang meluas ke wilayah-wilayah hinterlandnya. Sementara itu, hasil penelitian Goldblum dan Wong (2000) menunjukkan bahwa pada periode 1981-1990 laju pertumbuhan penduduk Bekasi sebesar 6\% lebih tinggi dibandingkan dengan laju pertumbuhan penduduk Bogor dan Tangerang sebesar 4\%. Penggunaan lahan untuk kawasan terbangun semakin lama semakin bertambah disebabkan oleh perkembangan pembangunan yang pesat untuk perumahan, industri dan perkantoran.

Dari uraian tentang permasalahan konsistensi data untuk analisis perubahan penggunaan lahan, adanya isu tentang dinamika yang sangat pesat di wilayah Kota Bekasi, serta rendahnya kontrol pemanfaatan ruang untuk mengikuti alokasi ruang dalam RTRW, penelitian ini bertujuan untuk: (1) mengetahui pola perubahan penggunaan lahan Kota Bekasi menggunakan citra beresolusi spasial tinggi, (2) mengidentifikasi dan membandingkan pemanfaatan ruang saat ini dan alokasi ruang menurut RTRW Kota Bekasi, (3) mengkaji perkembangan wilayah Kota Bekasi, serta (4) mengetahui faktor-faktor penyebab perubahan penggunaan lahan.

\section{BAHAN DAN METODE}

Penelitian ini dilakukan di Kota Bekasi dan analisis data dilakukan di studio Bagian Perencanaan Pengembangan Wilayah, Departemen Ilmu Tanah dan Sumberdaya Lahan, Fakultas Pertanian, Institut Pertanian Bogor.

Data yang digunakan dikelompokkan atas data primer dan sekunder tahun 2003 dan 2010. Data primer terdiri dari citra Quickbird tahun 2003 dan 2010 dan titik pengamatan lapang penggunaan lahan. Data sekunder terdiri atas data statistik Produk Domestik Regional Bruto (PDRB), Potensi Desa tahun 2003 dan 2006 yang meliputi jumlah fasilitas, aksesibilitas, dan jumlah penduduk. Disamping itu data sekunder juga berupa peta yang terdiri dari peta administrasi Kota Bekasi, peta Rencana Tata Ruang Wilayah (RTRW) Kota Bekasi tahun 2000-2010 yang diperoleh dari Badan Perencanaan Pembangunan Daerah Kota Bekasi dan Dinas Tata Ruang Kota Bekasi. Peralatan yang digunakan adalah Global Positioning System (GPS), kamera digital, seperangkat komputer dengan perangkat lunak ArcView GIS 3.3, Statistica 8.0, serta Office 2007.

\section{Analisis Data Peta dan Citra}

Proses analisis data penginderaan jauh dimulai dari koreksi geometrik citra dengan peta rupabumi skala 1:25,000. Selanjutnya, penggunaan lahan didelineasi secara manual dengan teknik interpretasi visual. Karakteristik obyek yang tergambar pada citra digunakan untuk mengenali obyek yang disebut interpretasi citra (Sutanto, 1994). Unsur-unsur interpretasi mencakup rona, bentuk, tekstur, pola, ukuran, bayangan, situs, dan asosiasi. Interpretasi digabungkan dengan pengamatan lapang digunakan untuk mengidentifikasikan tipe-tipe penggunaan lahan yang dikelaskan atas permukiman teratur, permukiman tidak teratur, kebun campuran, Tanaman Pertanian Lahan Basah (TPLB), Tanaman Pertanian Lahan Kering (TPLK), kawasan industri, Ruang Terbuka Hijau (RTH), fasilitas pendidikan, lahan kosong, Tempat Pemakaman Umum (TPU), Tempat Pembuangan Akhir (TPA), badan air, rumput, semak, dan ilalang. 


\section{Pengecekan Lapang}

Pengecekan lapang dilakukan dengan menggunakan GPS untuk mengambil data-data penggunaan lahan aktual serta untuk memverifikasi interpretasi citra sehingga data akhir memiliki keakuratan tinggi. Titik-titik cek lapang ditentukan dari poligonpoligon yang mengalami perubahan penggunaan lahan yang paling luas dan mewakili setiap wilayah administrasi. Selain itu, untuk memudahkan dalam pengecekan lapang, titik-titik yang dipilih yang dapat diakses dengan kendaraan beroda- 2 .

\section{Identifikasi Tingkat Perkembangan Wilayah}

Perkembangan wilayah di Kota Bekasi dianalisis dengan menggunakan metode skalogram sederhana. Metode ini digunakan untuk menentukan hirarki pusatpusat wilayah penopang yang mendukung wilayah pusat pelayanan aktivitas. Perkembangan suatu wilayah dianalisis dengan mengidentifikasi jumlah dan jenis fasilitas umum, dan jumlah penduduk di wilayah tersebut.

Wilayah yang berhirarki tinggi adalah wilayah yang memiliki jumlah unit dan jenis fasilitas yang paling banyak dan beragam. Peubah yang digunakan adalah jumlah fasilitas ekonomi (wartel, kiospon, warung internet, toko, warung, kios, pasar swalayan, supermarket, rumah makan, restoran, kedai makanan dan minuman, hotel, penginapan, industri kerajinan, bank umum, koperasi), jumlah fasilitas pendidikan (TK, SD, SLTP, SMU dan SMK, Akademi/Perguruan Tinggi Negeri dan yang sederajat), jumlah fasilitas kesehatan (rumah sakit, rumah sakit bersalin, poliklinik/balai pengobatan, puskesmas, puskesmas pembantu, apotek, tempat praktek dokter, tempat praktek bidan), dan jumlah fasilitas sosial (tempat peribadatan)

Penentuan tingkat perkembangan wilayah didasarkan atas nilai Indeks Perkembangan Desa (IPD) yang merupakan penjumlahan dari seluruh fasilitas di setiap unit wilayah kelurahan. Persamaan untuk menghitung IPD adalah seagai berikut:

$$
I P D_{j}=\sum_{i=1}^{p} X_{i j}
$$

dimana:

IPD = Indeks perkembangan desa;

$\mathrm{X}_{\mathrm{i}} \quad=$ Jumlah jenis/unit fasilitas ke-i di wilayah ke-j

Tingkat perkembangan ditetapkan dengan ketentuan sebagai berikut (1) Hirarki I: Jika nilai IPD lokasi ke-i lebih besar dari nilai simpangan baku dan rataan IPD seluruh wilayah; (2) Hirarki II: Jika nilai IPD lebih besar atau sama dengan rata-rata seluruh wilayah; (3) Hirarki III: Jika nilai IPD lebih kecil dari rata-rata IPD seluruh wilayah.

\section{Analisis Inkonsistensi Pemanfaatan Ruang}

Analisis inkonsistensi pemanfaatan ruang dilakukan melalui tumpang tepat peta penggunaan lahan dengan peta RTRW dan peta administrasi Kota Bekasi. Penetapan inkonsistensi dilakukan dengan terlebih dahulu membangun matriks logika inkonsistensi. Karena pembagian jenis penggunaan dan jenis alokasi ruang yang tidak senama, maka matrik ini menjadi jembatan untuk menilai penggunaan lahan dan kesesuaiannya dengan alokasi ruang. Matriks logik inkonsistensi dibangun mengikuti Listiawan (2010). Matriks logik ini terdiri dari klasifikasi kelas peruntukkan lahan pada RTRW Kota Bekasi dan klasifikasi penggunaan lahan.

\section{Analisis Regresi Berganda (Multiple Regression Analysis)}

Analisis regresi berganda digunakan untuk menduga nilai parameter peubah yang dihipotesiskan mempengaruhi terjadinya perubahan penggunaan lahan di Kota Bekasi. Proses analisis regresi dilakukan dengan perangkat lunak Statistica 8.0. Pendugaan koefisien regresi menggunakan prinsip regresi bertatar (stepwise regression). Prinsip dasar regresi bertatar menerapkan proses pengurangan jumlah peubah dalam persamaan dengan menambahkan peubah satu demi satu sampai diperoleh persamaan regresi yang paling baik (forwardstepwise).

Persamaan umum regresi untuk identifikasi faktor penentu perubahan penggunaan lahan tersebut adalah:

$$
\mathrm{Y}=\mathrm{A}_{1} \mathrm{X}_{1}+\mathrm{A}_{2} \mathrm{X}_{2}+\ldots \mathrm{AnXn}+\varepsilon
$$

dimana:

$\mathrm{Y}=$ Peubah respon yaitu luas perubahan penggunaan lahan (ha)

$\mathrm{X}_{\mathrm{i}}$ = Peubah-peubahpenduga ke-i yang dihipotesiskan mempengaruhi terjadinya perubahan penggunaan lahan, $i=1,2, \ldots$

$\mathrm{A}_{\mathrm{i}}=$ Koefisien regresi peubah ke-i

$\mathrm{E}=$ Galat model

Peubah-peubah respon yang dianalisis terdiri dari empat jenis pola perubahan, yaitu (1) luas perubahan penggunaan TPLB menjadi lahan terbangun (Pola-1 $=$ Y1), (2) luas perubahan TPLK menjadi lahan terbangun (Pola2=Y2), (3) luas perubahan lahan kosong menjadi lahan terbangun (Pola-3=Y3), dan (4) luas perubahan kebun campuran menjadi lahan terbangun (Pola-4=Y4). Jenis pola perubahan ini dipilih sesuai dengan fenomena utama yang ditemukan di wilayah studi.

Peubah penduga yang dihipotesiskan mempengaruhi perubahan penggunaan lahan antara lain laju pertambahan jumlah penduduk, laju pertambahan jumlah fasilitas (pendidikan, ekonomi, sosial, kesehatan), rataan jarak aksesibilitas ke pusat fasilitas, dan luas penggunaan lahan tahun 2003.

\section{HASIL DAN PEMBAHASAN}

\section{Penggunaan Lahan di Kota Bekasi}

Penggunaan lahan yang teridentifikasi dari Citra Quickbird antara lain permukiman teratur, permukiman tidak teratur, kebun campuran, TPLB, TPLK, kawasan industri, RTH, fasilitas pendidikan, lahan kosong, TPU, TPA, badan air, dan rumput, semak, ilalang.

Permukiman teratur yang merupakan sekumpulan bangunan yang digunakan sebagai tempat tinggal dengan bentuk, ukuran dan jarak rumah satu dengan yang lain 
seragam menyebar di seluruh kecamatan. Kecamatan Bekasi Utara, Bekasi Selatan, dan Rawalumbu memiliki luasan sebaran permukiman teratur terbesar. Sementara itu, permukiman tidak teratur dicirikan dengan sekumpulan bangunan dengan bentuk, ukuran, dan jarak antar rumah yang tidak seragam, berpola tidak teratur, dan berasosiasi dengan kebun campuran, perdagangan, jasa, dan perkantoran. Penyebaran permukiman tidak teratur terbesar di Kecamatan Pondok Gede, Bekasi Barat, dan Jati Asih.

Kawasan industri umumnya memiliki luasan yang besar. Di wilayah Kota Bekasi, kawasan industri hanya terdapat di beberapa kecamatan, yaitu Kecamatan Bantar Gebang, Mustika Jaya, Bekasi Barat, Bekasi Utara, Medan Satria, dan Rawalumbu. Kota Bekasi bagian Utara dan Selatan memiliki luasan sebaran kawasan industri terbesar.

Seluruh Kecamatan di Kota Bekasi memiliki ruang terbuka hijau. Ruang terbuka hijau merupakan jenis penggunaan lahan yang dikhususkan untuk jalur hijau jalan, jalur pengaman jalan dan sempadan sungai. Kecamatan Rawalumbu dan Bekasi Selatan adalah kecamatan yang memiliki sebaran RTH terluas.

TPLB merupakan lahan pertanian yang ditanami padi sebagai tanaman utama. Penggunaan lahan TPLB yang diamati merupakan gabungan dari berbagai fase tanaman padi. Persebaran luas terbesar TPLB di Kota Bekasi terdapat pada bagian Selatan Kota Bekasi, yaitu Kecamatan Bantar Gebang dan Kecamatan Mustika Jaya. Sebaliknya TPLK biasanya terdiri dari ladang dan tegalan, yang ditanami dengan tanaman semusim. Persebaran TPLK merata hampir di seluruh kecamatan, kecuali pada Kecamatan Pondok Gede. Luasan TPLK terbesar dijumpai di Kecamatan Mustika Jaya.

Kebun campuran di Kota Bekasi umumnya ditanami tanaman tahunan seperti melinjo, nangka, kelapa, pisang, dan lain-lain. Kebun campuran terletak berada di sekitar permukiman tidak teratur dan ditemukan merata di seluruh kecamatan di Kota Bekasi. Kecamatan Mustika Jaya dan Kecamatan Jati Asih memiliki sebaran luas kebun campuran terbesar.

Lahan kosong adalah lahan terbuka yang tanpa bangunan atau tanaman di atasnya. Biasanya lahan kosong semula merupakan lahan sawah yang direncanakan menjadi permukiman teratur oleh pihak-pihak swasta. Kecamatan Mustika Jaya dan Bekasi Utara adalah kecamatan yang memiliki luasan lahan kosong terbesar.

Fasilitas pendidikan merupakan bangunan yang digunakan untuk sarana pendidikan. Jenis tutupan ini didelineasi tersendiri karena karakteristiknya yang khas dan mudah diidentifikasi dari Citra Quickbird. Kecamatan Bekasi Timur dan Rawalumbu diidentifikasi memiliki luasan fasilitas pendidikan terbesar diantara kecamatan lainnya.

Tempat Pembuangan Akhir (TPA) biasanya jauh dari pusat kota. TPA hanya terdapat di Kecamatan Bantar Gebang. Hal ini sesuai dengan alokasi untuk TPA yang telah ditetapkan oleh pemerintah. Sementara itu badan air tidak merata di seluruh kecamatan. Beberapa kecamatan yaitu Kecamatan Pondok Gede, Bekasi Barat, Medan Satria, dan Kecamatan Pondok Melati tidak memiliki atau dilalui badan air.
TPU biasanya terletak jauh dan agak terpisah dari permukiman penduduk. Persebaran TPU hampir merata di seluruh kecamatan kecuali di Kecamatan Medan Satria, sedangkan rumput, semak dan ilalang banyak ditemukan di Kecamatan Jati Sampurna. Hasil interpretasi citra Quickbird tahun 2003 dan 2010 disajikan pada Gambar 1.

\section{Perubahan dan Pola Penggunaan lahan di Kota Bekasi}

Penggunaan lahan di Kota Bekasi sangat dinamis dan terus mengalami perubahan setiap tahunnya. Perbandingan struktur penggunaan lahan di Kota Bekasi pada tahun 2003 dan tahun 2010 disajikan pada Tabel 1.

Kelompok lahan terbangun, seperti permukiman tidak teratur, permukiman teratur, fasilitas pendidikan, dan kawasan industri meningkat cukup signifikan pada periode 2003-2010. Pada tahun 2010 luas kebun campuran menurun secara signifikan. Total penurunan kebun campuran sebesar $20 \%$ atau seluas 749 ha. Disamping kebun campuran, lahan kosong dan TPLB juga mengalami penurunan signifikan. Penurunan luas kebun campuran terbesar terjadi di Kecamatan Pondok Gede dan paralel dengan peningkatan luas penggunaan lahan pemukiman tidak teratur.

Terkait dengan peningkatan luas RTH sebesar 74.3 ha atau $10 \%$ sangat menggembirakan. Hasil penelitian Sitorus et al. (2011) di Jakarta Selatan justru menunjukkan hal yang sebaliknya dimana pada periode Tahun 20022007 (5 tahun) terjadi pengurangan luas RTH sebesar 362 ha. Penggunaan lahan Kota Bekasi secara spasial disajikan pada Gambar 1. Gambar tersebut menunjukkan penggunaan lahan Kota Bekasi bagian Barat yang berbatasan dengan wilayah DKI Jakarta dan Kota Bekasi bagian Timur yang dekat dengan pusat Kota Bekasi didominasi oleh ruang terbangun. Pola ini terbentuk dipengaruhi oleh aksesibilitas terhadap pusat kegiatan dan jaringan jalan yang memadai. Sementara itu, bagian Selatan Kota Bekasi yang berbatasan dengan Kabupaten Bogor dan bagian Utara yang berbatasan dengan Kabupaten Bekasi pada tahun 2003 masih didominasi oleh penggunaan lahan tidak terbangun.

Pada tahun 2010 penurunan luas penggunaan lahan terbesar terjadi di bagian Selatan Kota Bekasi yaitu Kecamatan Jati Asih dan Kecamatan Mustika Jaya. Terbentuknya jalan tol baru di sepanjang Kecamatan Jati Asih menyebabkan konversi lahan yang intensif. Salah satu jenis penggunaan yang mengalami perubahan terbesar adalah kebun campuran. Di Kecamatan Mustika Jaya, penurunan luas terbesar TPLB dikarenakan dikonversi menjadi perumahan teratur. Konversi lahan pertanian ke non pertanian menurut Winoto et al. (1996) adalah suatu proses yang bersifat tidak dapat balik. Konversi lahan pertanian umumnya akan dibarengi dengan perubahanperubahan orientasi ekonomi, sosial, budaya, dan politik masyarakat yang umumnya juga bersifat tidak dapat balik. 
Tabel 1. Luas penggunaan lahan tahun 2003, 2010, dan perubahannya

\begin{tabular}{lllcc}
\hline \multirow{2}{*}{ Jenis Penggunaan Lahan } & $\begin{array}{l}\text { Tahun } 2003 \\
\text { (ha) }\end{array}$ & $\begin{array}{l}\text { Tahun } 2010 \\
\text { (ha) }\end{array}$ & 20.4 & Perubahan \\
\cline { 3 - 5 } & 21.2 & 80.6 & -0.8 & $-4 \%$ \\
\hline Badan Air & 79.9 & 629 & 0.7 & $1 \%$ \\
Fasilitas Pendidikan & 603 & 3,072 & 26.6 & $4 \%$ \\
Kawasan Industri & 3,820 & 1,898 & -749 & $-20 \%$ \\
Lahan Kosong & 2,256 & 6,585 & -358 & $-16 \%$ \\
Permukiman Tidak Teratur & 5,511 & 4,767 & 1,074 & $19 \%$ \\
Permukiman Teratur & 3,994 & 800 & 773 & $19 \%$ \\
Ruang Terbuka Hijau & 726 & 1,124 & 74.3 & $10 \%$ \\
Rumput,semak,ilalang & 1,352 & 161 & -227 & $-17 \%$ \\
Tempat Pembuangan Akhir & 159 & 1,816 & -598 & $-1 \%$ \\
Tanaman Pertanian Lahan Basah & 2,413 & 280 & -80.9 & $-22 \%$ \\
Tanaman Pertanian Lahan Kering & 361 & 62.8 & 0.0 & $0 \%$ \\
Tempat Pemakaman Umum & 62.8 & & & $-2 \%$ \\
\hline
\end{tabular}

\section{Analisis Inkonsistensi Pemanfaatan Ruang di Kota Bekasi}

Analisis inkonsistensi pemanfaatan ruang terhadap RTRW dilakukan untuk mengetahui apakah pemanfaatan ruang yang telah dilakukan sudah sesuai dengan Rencana Tata Ruang Wilayah (RTRW). Bentuk realisasi dari RTRW adalah pemanfaatan ruang yang terjadi di suatu wilayah. Luas dan proporsi total inkonsistensi Kota Bekasi tahun 2003 dan 2010 disajikan pada Tabel 2.

Hasil analisis inkonsistensi pemanfaatan ruang tahun 2003 terhadap RTRW periode 2000-2010 menunjukkan persentase jenis inkonsistensi terbesar terhadap luas peruntukkan terjadi pada jenis peruntukkan taman/hutan kota menjadi ruang terbangun, lahan kosong, dan lahan pertanian.

Pada tahun 2010, persentase jenis inkonsistensi terbesar terhadap luas peruntukkan terjadi pada jenis peruntukkan taman/hutan kota yang saat ini justru digunakan untuk ruang terbangun, lahan kosong, dan lahan pertanian. Luas inkonsistensi paling besar terdapat di Kecamatan Mustika Jaya yang merupakan pemekaran dari Kecamatan Bantar Gebang yaitu sebesar 146 ha atau $5.66 \%$ dari luas wilayah Kecamatan Mustika Jaya sebesar 2,577 ha.

Besarnya inkonsistensi pemanfaatan ruang pada Kecamatan Bantar Gebang pada tahun 2003 dan Kecamatan Mustika Jaya pada tahun 2010 yang merupakan pemekaran dari Kecamatan Bantar Gebang terjadi karena luas penggunaan lahan di kecamatan ini didominasi oleh penggunaan lahan pertanian dan lahan kosong yang memiliki nilai land rent rendah. Hal ini mendorong masyarakat mengkonversikan lahannya menjadi jenis penggunaan lahan dengan nilai land rent lebih tinggi. Jarak kecamatan yang jauh dari pusat kota juga menyebabkan rendahnya pengawasan aparat terhadap segala bentuk penyimpangan pemanfaatan ruang (Listiawan, 2010).
Tabel 2. Luas dan proporsi total inkonsistensi Kota Bekasi Tahun 2003 dan 2010

\begin{tabular}{lllllc}
\hline Jenis Inkonsistensi & \multicolumn{2}{c}{ Tahun 2003 } & \multicolumn{2}{c}{ Tahun 2010 } \\
\hline Peruntukan RTRW & $\begin{array}{l}\text { Kondisi } \\
\text { Eksisting }\end{array}$ & ha & $\%$ & ha & $\%$ \\
\hline Pertanian & $\begin{array}{l}\text { Ruang } \\
\text { terbangun } \\
\text { Ruang } \\
\text { Sempadan sungai }\end{array}$ & 172 & 0.8 & 227 & 1.1 \\
terbangun & 43.5 & 0.2 & 58.8 & 0.3 \\
Taman/hutan kota & $\begin{array}{l}\text { Ruang } \\
\text { terbangun }\end{array}$ & 53.1 & 0.3 & 59.9 & 0.3 \\
Taman/hutan kota & $\begin{array}{l}\text { Lahan } \\
\text { kosong }\end{array}$ & 17.7 & 0.1 & 8.7 & 0.0 \\
Taman/hutan kota & $\begin{array}{l}\text { Pertanian } \\
\text { Ruang } \\
\text { terbangun }\end{array}$ & 8.5 & 0.0 & 16.7 & 0.1 \\
Rekreasi/olahraga & 6.2 & 301 & 1.4 & 377 & 1.8 \\
\hline Jumlah & & & & & 0.2 \\
\hline
\end{tabular}

\section{Tingkat Perkembangan Wilayah di Kota Bekasi}

Perkembangan suatu wilayah umumnya selalu diikuti dengan pertumbuhan jumlah penduduk (Hartini et al., 2008). Pertumbuhan penduduk ini berimplikasi pada peningkatan kebutuhan kualitas dan kuantitas sarana dan prasarana. Hasil identifikasi tingkat perkembangan wilayah. Kota Bekasi dengan menggunakan analisis skalogram disajikan pada Tabel 3. Tabel 3 menyajikan persentase jumlah kelurahan berdasarkan hirarki di setiap kecamatan di Kota Bekasi.

Tabel 3. Persentase kelurahan berdasarkan hirarki wilayah $\mathrm{d}$ setiap kecamatan

\begin{tabular}{|c|c|c|c|c|c|c|}
\hline \multirow{3}{*}{$\begin{array}{l}\text { Nama } \\
\text { Kecamatan }\end{array}$} & \multicolumn{3}{|c|}{ Hirarki tahun 2003} & \multicolumn{3}{|c|}{ Hirarki tahun 2006} \\
\hline & I & II & III & I & II & III \\
\hline & \multicolumn{3}{|c|}{$\%$} & \multicolumn{3}{|c|}{$\%$} \\
\hline Pondok Gede & 20 & 80 & 0 & 20 & 60 & 20 \\
\hline Bekasi Timur & 75 & 25 & 0 & 75 & 25 & 0 \\
\hline Bekasi Selatan & 20 & 40 & 40 & 40 & 60 & 0 \\
\hline Bantargebang & 0 & 25 & 75 & 0 & 25 & 75 \\
\hline Medan Satria & 25 & 75 & 0 & 0 & 100 & 0 \\
\hline Bekasi Barat & 20 & 20 & 60 & 0 & 100 & 0 \\
\hline Rawalumbu & 0 & 25 & 75 & 0 & 75 & 25 \\
\hline Jatiasih & 0 & 33 & 67 & 0 & 33 & 67 \\
\hline Jatisampurna & 0 & 0 & 100 & 0 & 20 & 80 \\
\hline Bekasi Utara & 0 & 67 & 33 & 0 & 50 & 50 \\
\hline Kota Bekasi & 13 & 38 & 48 & 13 & 46 & 41 \\
\hline
\end{tabular}




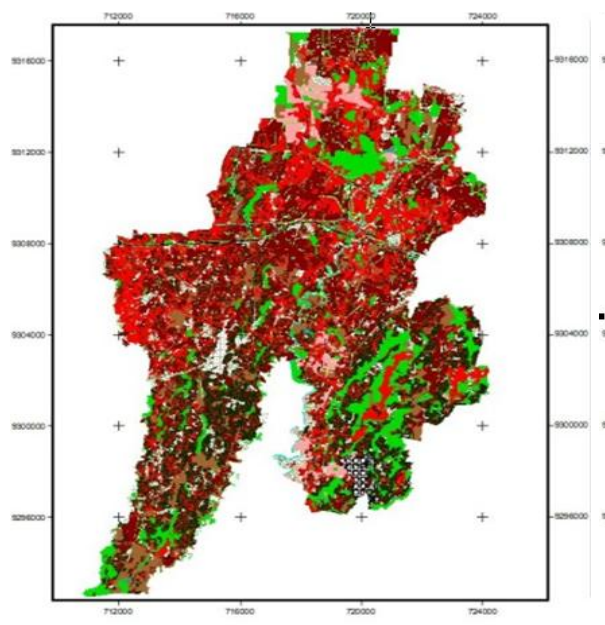

a.
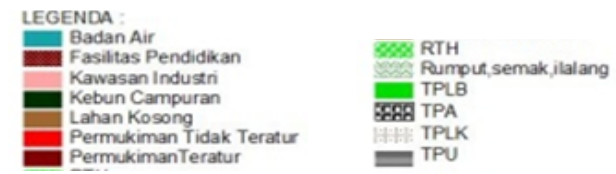
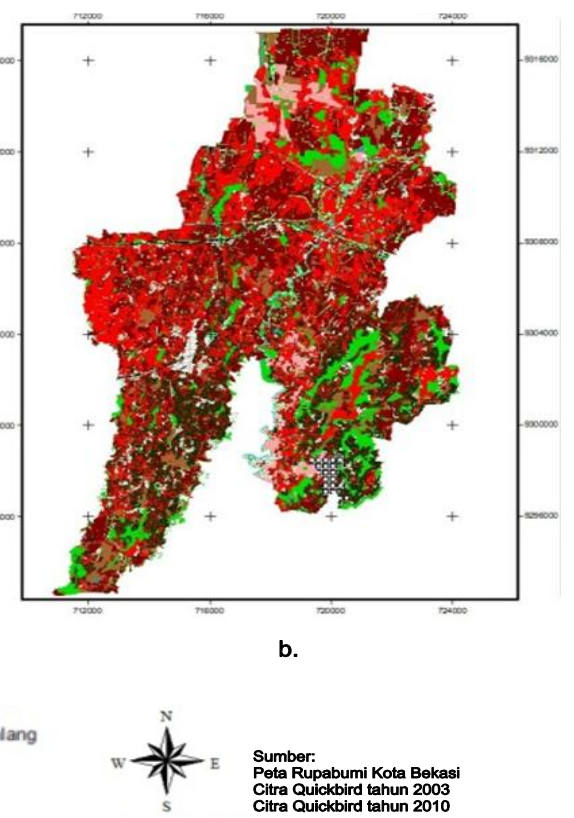

Gambar 1. Peta penggunaan lahan Kota Bekasi (a) tahun 2003 dan (b) tahun 2010

Secara spasial kecamatan-kecamatan di bagian Utara, Barat, dan Timur Kota Bekasi cenderung memiliki hirarki lebih tinggi dibandingkan dengan kecamatan di bagian Selatan. Kecamatan yang terletak di sebelah Utara dan Barat Kota Bekasi berbatasan dengan wilayah DKI Jakarta. Sementara di sebelah Timur menjadi pusat ibukota Bekasi. Oleh karena itu, kecamatan-kecamatan tersebut memiliki tingkat perkembangan lebih tinggi dibandingkan dengan wilayah bagian Selatan. Selain itu, wilayahwilayah tersebut memiliki jumlah penduduk yang tinggi sehingga mendorong untuk terjadinya penambahan jumlah dan jenis fasilitas. Hasil analisis skalogram pada tahun 2003 dan 2006 menunjukkan adanya perubahan komposisi wilayah menurut struktur hirarki I hingga III. Pada tahun 2006 jumlah hirarki 2 lebih banyak dibandingkan dengan hirarki III. Kondisi ini berlawanan dengan hasil analisis di tahun 2003. Hasil analisis tersebut menunjukkan adanya peningkatan pemerataan pembangunan fasilitas pelayanan di seluruh lokasi ditandai dengan menurunnya jumlah wilayah berhirarki III dan meningkatnya jumlah wilayah berhirarki II.

\section{Hubungan Perubahan Luas Penggunaan Lahan dengan Perkembangan Wilayah}

Selanjutnya untuk mengetahui keterkaitan antara perubahan penggunaan lahan dengan perkembangan wilayah, dibangun tabulasi silang antara kedua peubah. Selanjutnya hasil tabulasi silang tersebut digambarkan dalam histogram sebagaimana disajikan pada Gambar 2. Gambar 2 menunjukkan bahwa wilayah-wilayah yang memiliki hirarki tinggi didominasi penggunaan lahan terbangun sehingga perubahan penggunaan lahan menjadi lahan ruang terbangun secara relatif lebih rendah dibandingkan dengan wilayah lain dengan hirarki lebih rendah.

Penggunaan lahan di wilayah berhirarki I didominasi oleh ruang terbangun yang digunakan untuk berbagai aktivitas ekonomi, sehingga peluang untuk mengalami konversi lahan menjadi lebih kecil. Sebaliknya, wilayah-wilayah yang memiliki hirarki rendah banyak mengalami peningkatan penggunaan lahan terbangun.

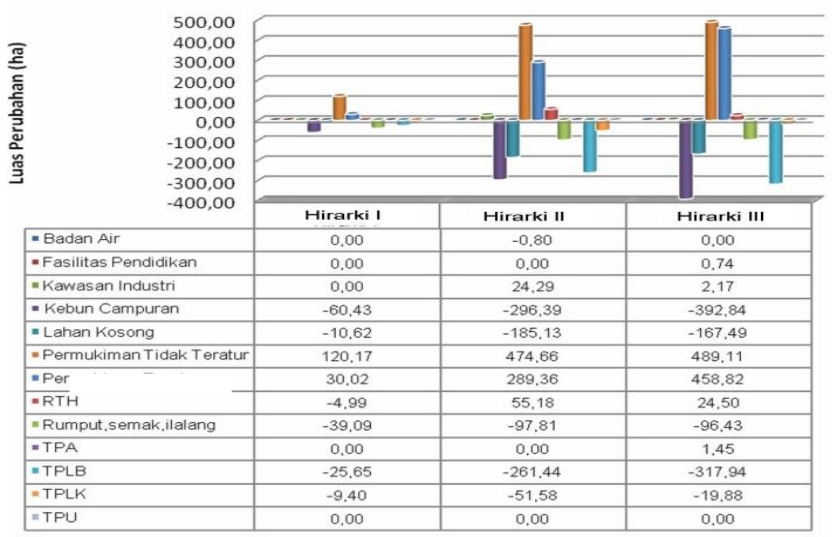

Gambar 2. Perubahan luas penggunaan lahan pada ketiga hirarki wilayah

Hal ini diduga karena penggunaan lahan nonruang terbangun di wilayah tersebut masih sangat luas sehingga potensial terkonversi menjadi penggunaan lahan ruang terbangun. Semakin tinggi hirarki (hirarki I) maka luas perubahan penggunaan lahan menjadi ruang terbangun semakin kecil. Dibandingkan dengan wilayah yang memiliki hirarki yang lebih rendah, wilayah berhirarki I mengalami perubahan luas total lebih kecil dan diduga suatu saat tidak mengalami perubahan sama sekali karena tidak ada lahan lagi yang bisa dikonversikan.

Wilayah-wilayah yang berhirarki III mengalami perubahan luas penggunaan lahan terbesar. Peningkatan luas penggunaan lahan terbesar pada hirarki III terjadi pada jenis penggunaan pemukiman tidak teratur sebesar 489 ha, diikuti dengan perumahan teratur sebesar 459 ha. Sementara itu, penurunan luas penggunaan lahan terbesar terjadi pada jenis penggunaan kebun campuran 393 ha, diikuti dengan TPLB sebesar 318 ha. 
Tabel 4. Nilai koefisien regresi perubahan penggunaan lahan

\begin{tabular}{|c|c|c|c|c|}
\hline Peubah yang berpengaruh nyata & Y1 & Y2 & Y3 & Y4 \\
\hline Alokasi pertanian $(\mathrm{x} 1)$ & -0.29 & & & 0.09 \\
\hline Alokasi lahan terbangun (x2) & 0.20 & 0.79 & 0.37 & \\
\hline Alokasi hutan kota (x3) & -0.14 & & & \\
\hline Aksesibilitas ke kota lain terdekat (x4) & -0.13 & & 0.28 & \\
\hline Aksesibilitas ke kecamatan (x5) & & 0.21 & & \\
\hline Aksesibilitas ke pusat fasilitas sosial (x6) & & 0.07 & & -0.07 \\
\hline Aksesibilitas Ke Pusat Fasilitas ekonomi (X7) & & 0.27 & & \\
\hline Luas lahan terbangun 2003 (x8) & & -0.60 & & 0.11 \\
\hline Luas TPLK 2003 (X9) & & 0.66 & & \\
\hline Luas TPLB 2003 (X10) & 0.90 & & -0.43 & 0.01 \\
\hline Luas kebun campuran 2003(x11) & & -0.87 & 0.39 & \\
\hline Luas lahan kosong 2003 (x12) & & & & 0.85 \\
\hline Fasilitas sosial (x13) & & -0.17 & & 0.20 \\
\hline Fasilitas kesehatan (x14) & & -0.36 & & \\
\hline Fasilitas pendidikan (x15) & -0.19 & & 0.17 & \\
\hline Fasilitas ekonomi (x16) & & & 0.16 & \\
\hline Jumlah penduduk (x17) & & -0.16 & & 0.10 \\
\hline R-square & 0.65 & 0.43 & 0.57 & $\mathbf{0 . 8 4}$ \\
\hline \multicolumn{5}{|l|}{ Keterangan: } \\
\hline Y1 = Perubahan TPLB menjadi Lahan & gun & & & \\
\hline$=$ Perubahan TPLK menjadi Lahan & igun & & & \\
\hline$=$ Perubahan Kebun Campuran men & ahan $\mathrm{Te}$ & & & \\
\hline Y4 = Perubahan Lahan Kosong menjad & n Terb & & & \\
\hline
\end{tabular}

\section{Faktor-Faktor yang Mempengaruhi Perubahan Penggunaan Lahan}

Perubahan penggunaan lahan terjadi karena peningkatan kebutuhan akan ruang dihadapkan pada ketersediaan lahan yang terbatas. Penggunaan lahan nonterbangun seperti TPLB, TPLK, kebun campuran, lahan kosong merupakan lahan yang mudah dikonversikan menjadi penggunaan lahan terbangun seperti permukiman teratur, permukiman tidak teratur, kawasan industri, dan fasilitas pendidikan.

Analisis perubahan penggunaan lahan dilakukan pada beberapa jenis pola perubahan, yaitu perubahan penggunaan lahan TPLB menjadi lahan terbangun (disimbolkan dengan Y1), perubahan penggunaan TPLK menjadi lahan terbangun (Y2), perubahan penggunaan lahan kebun campuran menjadi lahan terbangun (Y3), dan perubahan penggunaan lahan kosong menjadi lahan terbangun (Y4). Hasil dari analisis disajikan pada Tabel 4.

Nilai koefisien determinan $\left(\mathrm{R}^{2}\right)$ persamaan regresi pada Tabel 4 untuk Y1, Y2, Y3, dan Y4 berturut-turut adalah $0.65 ; 0.43 ; 0.57 ; 0.84$. Nilai $\mathrm{R}^{2}$ tersebut mendekati 1, menunjukkan bahwa pemilihan peubah penduga sudah relatif tepat. Namun, tidak semua nilai koefisien determinan mendekati 1 . Selanjutnya berdasarkan Tabel 4, nilai parameter hasil analisis regresi dapat dikelompokkan menjadi dua, yaitu peubah yang berpengaruh sangat nyata $(\alpha=0.05)$ dan peubah yang berpengaruh nyata $(\alpha=0.10)$.

Identifikasi faktor penentu pola perubahan pertama (Y1) menunjukkan peubah yang berpengaruhsangat nyata adalah alokasi RTRW untuk kawasan terbangun dan kawasan pertanian, serta luas TPLB tahun 2003. Peubah yang berperan positif adalah alokasi RTRW untuk lahan terbangun dan luas TPLB pada tahun 2003, sedangkan alokasi RTRW untuk pertanian berperan negatif.

Pola perubahan penggunaan lahan ke-2 (Y2=TPLK menjadi lahan terbangun) dipengaruhi oleh peubah luas penggunaan lahan (TPLK, kebun campuran, lahan terbangun) tahun 2003, alokasi kawasan terbangun, dan pertambahan fasilitas kesehatan. Peubah yang berperan positif adalah luas TPLK tahun 2003 dan alokasi kawasan terbangun, sebaiknya tiga peubah lain berperan negatif. Luas TPLK dan alokasi RTRW untuk kawasan terbangun menjadi pemicu terjadinya perubahan pola- 2 .

Selanjutnya, pola perubahan luas penggunaan lahan ke-3 (Y3= perubahan penggunaan lahan kebun campuran menjadi lahan terbangun) menunjukkan terdapat 3 peubah, sangat nyata yang berperan positif yaitu alokasi lahan terbangun, aksesibilitas ke kota lain, dan luas kebun campuran pada tahun 2003. Sementara peubah luas TPLB tahun 2003 berperan negatif terhadap perubahan luas pola3.

Identifikasi faktor penentu luas perubahan pola ke-4 (perubahan penggunaan lahan kosong menjadi lahan terbangun) didorong oleh ketersediaan lahan kosong pada tahun 2003 dan laju pertambahan fasilitas sosial.

Dari seluruh hasil identifikasi faktor pemicu pada empat pola perubahan penggunaan lahan, secara konsisten alokasi ruang untuk kawasan terbangun menjadi faktor penting yang memicu terjadinya perubahan penggunaan lahan menjadi lahan terbangun. Alokasi ruang untuk lahan terbangun merupakan kebijakan pemerintah yang mendorong terjadinya proses perubahan, sementara itu dan luas kebun campuran serta semakin kedekatan jarak menuju ke wilayah kota menyebabkan perubahan penggunaan lahan kebun campuran menjadi lahan terbangun semakin potensi pembangunan fisik semakin tinggi. Terkait dengan perubahan penggunaan lahan pertanian.

Hasil penelitian Sitorus et al. (2009) di Kabupaten Tangerang menunjukkan laju konversi lahan pertanian (TPLK dan TPLB) sebesar 2,409 ha atau $2.4 \%$ per tahun. Faktor-faktor yang berpengaruh nyata terhadap laju konversi lahan pertanian adalah PDRB sektor jasa, sektor pertanian, sektor industri pengolahan, fasilitas pendidikan dan ekonomi, aksesibilitas ke pusat pemerintahan dan ke fasilitas kesehatan. 


\section{SIMPULAN}

1. Penggunaan lahan terbangun di Kota Bekasi dari tahun 2003 sampai 2010 mengalami peningkatan cukup signifikan terkait dengan pembangunan fasilitas pendidikan, kawasan industri, permukiman tidak teratur, dan permukiman teratur dari semula sebesar 10,187 ha (47.1\%) menjadi 12,061 ha (55.8\%).

2. Kondisi penggunaan lahan aktual di Kota Bekasi tahun 2003 menunjukkan ketidakpatuhan pemanfaatan lahan dengan alokasi pemanfaatan ruang sebesar 301 ha dan tahun 2010 sebesar 377 ha. Proporsi ketidakpatuhan terbesar pada tahun 2003 dan 2010 adalah terhadap alokasi lahan untuk taman/hutan kota yang di lapang justru digunakan sebagai lahan terbangun, lahan kosong, atau lahan pertanian.

3. Pada tahun 2003 kurang lebih $48 \%$ kelurahan memiliki hirarki III dan pada tahun 2006 46\% kelurahan berhirarki II.

4. Semakin tinggi hirarki suatu wilayah kecenderungan perubahan penggunaan lahan semakin kecil, kecuali perubahan RTH semakin meningkat. Jenis penggunaan lahan dominan di wilayah berhirarki tinggi adalah lahan terbangun untuk berbagai aktivitas ekonomi.

5. Faktor-faktor yang mempengaruhi perubahan penggunaan lahan menjadi lahan terbangun di Kota Bekasi secara signifikan adalah alokasi RTRW untuk lahan terbangun, alokasi RTRW untuk pertanian, luas TPLB tahun 2003, luas kebun campuran tahun 2003, luas TPLK tahun 2003, luas lahan kosong tahun 2003, dan aksesibilitas ke kota atau kabupaten lain.

\section{SARAN}

1. Penelitian ini menghasilkan data luas penggunaan lahan, dan pola perubahan penggunaan lahan. Penelitian lebih lanjut diperlukan untuk membuat prediksi penggunaan lahan pada beberapa tahun yang akan datang dengan menggunakan data series pada tahun sebelumnya.

2. Agar penyimpangan penggunaan lahan terhadap rencana tata ruang dapat dikendalikan dan diperkecil, Pemerintah Kota Bekasi disarankan untuk meningkatkan pemantauan dan pengawasan, khususnya pada lokasi-lokasi yang mengalami penyimpangan dari alokasi RTRW yang telah ditetapkan.

\section{DAFTAR PUSTAKA}

Firman, T. 2009. The continuity and change in megaurbanization in Indonesia: A survey of JakartaBandung Region (JBR) development. Habitat International, 33:327-339.

Goldblum, C. and Wong T-C. 2000. Growth, crisis and spatial change: a study of haphazard urbanization in Jakarta Indonesia. Land Use Policy, 17:29-37.
Hartini, S., Harintaka, dan Istarno. 2008. Analisis konversi ruang terbuka hijau menjadi penggunaan perumahan di Kecamatan Tembalang Kota Semarang. Media Teknik, 470-478.

Irawan, B. 2005. Konversi lahan sawah: potensi dampak, pola pemanfaatannya dan faktor determinan. Forum Penelitian Agro Ekonomi, 23:1-18.

Irawan, B. 2008. Meningkatkan efektifitas kebijakan konversi lahan. Forum Penelitian Agro Ekonomi, 26:116-131.

Listiawan, T. 2010. Hubungan antara kelas jalan dengan kecenderungan inkonsistensi pemanfaatan ruang di Kota Bogor Tahun 2003 dan Tahun 2007 [Skripsi]. Institut Pertanian Bogor. (Tidak dipublikasikan).

Rustiadi, E. dan D.R. Panuju. 1999. Suburbanisasi Kota Jakarta. Makalah dipresentasikan pada Seminar Tahunan VII Persada. Bogor, 6 Desember 1999.

Ruswandi, A., E. Rustiadi, dan K. Mudikdjo. 2007. Konversi lahan pertanian dan dinamika perubahan penggunaan lahan di Kawasan Bandung Utara. $J$. Tanah Lingk., 9:63-70.

Sitorus, S.R.P., R. Putri, dan D.R. Panuju. 2009. Analisis konversi lahan pertanian di Kabupaten Tangerang. J. Tanah Lingk., 11:41-48.

Sitorus, S.R.P., W. Aurelia, dan D.R. Panuju. 2011 Analisis perubahan luas ruang terbuka hijau dan faktor-faktor yang mempengaruhinya di Jakarta Selatan. Jurnal Landskap Indonesia, 3:15-20.

Sutanto. 1994. Penginderaan Jauh Jilid I. Gadjah Mada University. Yogyakarta.

Verburg, P.H., T.A. Veldkamp, and J. Bouma. 1999. Land use change under the conditions of high population pressure. Global Environmental Change, 9:313-302.

Verburg, P.H., P.P. Schot, M.J. Dijst, and A. Veldkamp. 2004. Land use change modelling: current practice and research priorities. GeoJournal, 61:309-324.

Winoto, J., N.A. Achsani, B. Barus, D.R. Panuju, F. Tonny, dan M.N. Aidi. 1996. Konversi lahan dan dampaknya terhadap keberlangsungan sistem pertanian di pantai utara Jawa Barat. Laporan Penelitian. Kerjasama LP-IPB dan ARMP, Badan Penelitian dan Pengembangan Pertanian, Departemen Pertanian. (Tidak dipublikasikan). 